\title{
THE BEHAVIORAL ECONOMICS: AN INFLUENCE OF PSYCHOLOGICAL FACTORS ON THE ECONOMIC GROWTH
}

\author{
Dmitry Vukolov Mikhailovich ${ }^{1}$ \\ Financial University under the Government of the Russian Federation, \\ Moscow, Russia \\ CMESTE \\ JEL Category: D91, E71
}

\begin{abstract}
Psychology as a branch of science could not take its place in the world for a long time. This fact says about a huge omission of a mass of intelligence by a human. However, the time overtook its own, and psychology became more significant for people and the economy in general. Being a science that would not exist without a human, it is impossible to omit its influence in it. Therefore, the main goal of this work is to consider the influence of behavioral mechanisms on decision-making by economic agents and, as a result, on economic growth. The theoretical part is closely interconnected with the practical part. This explains why the article does not have a clear separation between the two ones. Openings within the frame of behavioral economics embrace both the present and the past, which are aimed at showing both the fundamental nature of this knowledge and its undisputable relevance. These factors together represent a brief history of the development of this branch of knowledge. Through the prism of the main achievements of scientists of different years in the sphere of behavioral economics the irrational behavior of consumers was analyzed. This behavior was reflected in the examples, which showed simultaneously both: the main flaws of the classical macroeconomic models, and the importance of considering behavioral economics when analyzing aggregate demand and aggregate supply.
\end{abstract}

Keywords: behavioral economics, decision making, effect, expectations, inflation, economic growth, rationality

The address of the corresponding author:

Dmitry Vukolov Mikhailovich

表”dmitrii.vukolov@mail.ru

\section{INTRODUCTION}

Economics is one of those sciences that has the peculiarity of constantly developing and supplementing itself with new and new aspects, which, it would seem, should contribute to its understanding, but in practice, they complicate the subject even more. This is facilitated by the person

\footnotetext{
1 Scientific supervisor: Dinara Orlova Rustemovna

Department of Economic Theory, Financial University under the Government of the Russian Federation, Moscow, Russia
} 
who is the central element because without him the very concept of economy as a system of social relations would just be impossible. A person is the subject of the economy that is most difficult to formalize. This statement means that it mostly needs to be studied. This fact determines the relevance of this topic. The results of economic policy entirely depend on the level of understanding of humans' decision-making mechanisms. But how will it change?

The article is an attempt to prove that the regularities of behavioral economics can have a significant impact on economic growth.

To prove our hypothesis, we are going to rely on the works of the classics (Adam Smith, John Keynes). All of them create the underlying base to which some research by the founders of behavioral economics (Daniel Kahneman, Herbert Simon, and Richard Thaler) will be complemented.

As we already mentioned, human is the central link of the economy. Without him, the economy would not exist, but with him, it becomes so complicated that every century a new generation of scientists discovers new and new facets of a person and the economy as a whole. Each such new facet of the human personality and its role in the economic process was described by different paradigms. A fundamental example is the A. Smith's model, also known as "homo economicus", which is quite a long time dominated as a support for the understanding of the human role in the economy, though it was not the only one: to some extent, it is complemented by the other paradigms, each of which gave policies, institutions, norms and values and other important concepts the primacy of influence on a human.

Every action and shift of thought entail a certain chain of events that led a person to this type of thinking, to reasoning in this new framework. Thus, the Great Depression in the 1930s became a strong impetus for the studying of consumers' psychology. It has increased the concern of policymakers and scientists about the empirical significance of the standard model of rational agents' behavior in macroeconomics. The first steps to understanding were the works of a representative of the Cambridge school, John Maynard Keynes, who formulated the basic psychological law describing the dynamics of income and consumption dependence, introduced the concepts of the crowd effect, waves of pessimism and optimism, propensity to save and consumption. In the second third of the $X X$ century, the world saw the work of John Cohen, which includes a new paradigm "homo psychologicus", which promotes the idea that psychological factors have a significant impact on the decision of a person as an economic subject. It is impossible not to say that the financial crisis of 2007-2008 which clearly showed the failure of existing macroeconomic models also became a significant impetus to the studying of consumers' psychology. In November 2010, the President of the European Central Bank (ECB), Jean-Claude Trichet, expressed the following concerns: "When the crisis came, the serious limitations of existing economic and financial models became immediately apparent. Macro models failed to predict the crisis and seemed to be unable to explain convincingly what was happening to the economy." (Nikiforov \& Antipina, 2016) All this together means that it is impossible to ignore the connection of the two sciences: psychology and economics because only considering them together can provide comprehensive (at this stage of the development of economics) information about the economic processes.

To understand the limitations of classical models of macroeconomics about the developing behavioral economy, it is necessary to understand what exactly human features exist which are not included in the classical models. And at this stage, it is very important to understand that there are different factors and different levels of generalization in various works of different authors.

Thus, O. N. Patosha in his article divides factors into personal (such as personality properties, state, and various processes at the mental level) and situational (i.e., the influence of the environment) (Hommes, 2018). T. V. Kornilova, in turn, identifies risk-taking and rationality as psychological features of decision-making, as well as cognitive styles and characteristics of a person, which are particularly strong in her research of decision-making in dialogue with a computer (Kornilova \& Tikhomirov, 1990)

Referring to western society, we will see a slightly different picture. Sidney Dietrich, an educator at 
Walden University in Minneapolis, consolidating information from other sources, states that significant factors include experience, various cognitive distortions, escalating commitment and lost results, individual differences, including age and socioeconomic status, and a belief in personal significance. All this, he believes, affects the decision-making and decision-making process. (Pocheptsov, 2016)

So now it seems to be clear how convoluted behavioral economics is. But this intelligence was essential to be said because it mostly fits for forming the general impression. Now it is time to cover one more piece of key information that deserves to be paid attention to. Now all the thoughts and discoveries are going to be reinforced by the examples in terms of science, modern life, and the past.

\section{RESEARCH}

As I mentioned earlier it is more rational to emphasize the most basic factors out of the whole massive discoveries of behavioral economics. After this, we should better consider their impact on the macroeconomic situation. For this, it would be preferable to go back to the middle of the $X X$ century to study Herbert Simon's work, whose authoritative opinion is proved by the Nobel prize in the sphere of economics which he received in 1978. The scientist studied the decision-making process, which plays a key role in economic processes and as a result in economic grows and drops. "People are intentionally rational, but they have this ability only to a limited extent...". So, in this statement we can observe the idea of "bounded rationality", which implies memory that is not perfect, not always a correct assessment of future events, not immeasurable cognitive and mental abilities, and so on. The idea of "bounded rationality" (it is also worth noting that this idea was promoted in the future by Richard Tyler, who will be discussed later) was presented by Herbert Simon in contrast to the neoclassical ideal of considering human behavior in the economic process. A human, from the point of view of the neoclassicists, had an inert and unchanging nature, which was found contradictory not only by Simon Herbert himself, but also, for instance, Torstein Veblen - the founder of institutionalism. (Otrokhova, 2013)
Thus, bounded rationality is more or less related to every person as an economic agent. But, in what situations can this behavioral feature have the greatest impact on the macroeconomic environment? It is known that the most stressful situation for consumers is the economic crisis. And it is important to understand that panic among the smallest market participants, a person, appears much earlier than the potential crisis itself. Firstly, there are some consumer's expectations to be formed. They can be based on both objective and non-objective factors, which is explained by the concept of bounded rationality because the consumer is not always able to correctly assess the future situation in the market. At this stage, another psychological effect will be activated the crowd effect. Some light was spilled on this effect as early as 1895 when G. Lebon introduced the term "group consciousness". He suggested that getting into a crowd, a person who experiences its influence becomes poorly controlled and unpredictable (Kahneman \& Tversky, 2003). Everything happens as Lebon himself suggested: an individual when he gets into a crowd, not necessarily physical, but even informational simultaneously goes under its influence. This means that the probability that an individual will act in the same way as a crowd increases at times. Thus, an individual, looking at the behavior of another individual, is highly likely to act like the last one. And expectations, for example, inflationary ones, which are most strongly escalated during the crisis, acquire the format of an information cascade, which implies deciding which is not only based on their assessment but also based on observing the behavior of other market agents.

It was mentioned earlier that Herbert Simon's theory was put forward in opposition to the neoclassical theory. However, this model can be clarified by adding consumer inflation expectations. The modern neoclassical model of labor market equilibrium includes the differentiation of inflationary expectations of economic agents and the nominal level of inflation, which is expressed in price changes. This difference is the motive for deciding. So, naturally including price expectations in the function of wages, as well as in the aggregated labor supply (AS), the price level begins to depend directly on the expectations of inflation. This can be proved 
by the macroeconomic formula (1), which sets the total nominal wage, where $\mathrm{W}$ is the nominal wage, $P^{e} \quad$ is the expected price level, $u$ is the unemployment rate in the country, and $z$ is all other factors that can affect wages.

$$
W=P^{e} F(u, z)
$$

This will affect the equilibrium of $A D$ and $A S$. So, it seems to be that when price expectations increase, the level of nominal wages which is set by agents who express the demand for labor will also increase. .This non-price factor of aggregated supply significantly affects aggregated demand. The curves change their position to reflect price expectations, which force a review of pay. And as you know, labor remuneration is one of the most significant production costs. As we know the more the costs are the more the price for products is. This is also evident from formula (2), which is derived from formula (3)

$$
P=P^{e}(1+\mu) F(u, z)
$$

Where $\mu$ is the cost addition in price

$$
P=(1+\mu) W
$$

The amount of costs affects the price level of goods produced. An increase in price, with an expected high level of inflation, causes a decrease in aggregate demand because the price that the consumer will be willing to pay will be significantly lower than the price for which the producer is willing to sell the product. So, the analysis of this example in the framework of pricing in the economy shows that prices are set at the level at which they are seen by economic agents (Makashova, 2015). This indicates the importance of behavioral economics in modern models.

Other equally influential scientists are George Caton, to whom we owe the very concept of "behavioral economics" and Daniel Kahneman, who considered behavioral economics as a sphere of the economy that is studied about the cognitive, emotional, and social factors that influence the decision-making. However, this decision, according to Kahneman, may not take into account certain destructive consequences that indicate an initially incorrect assumption made within the framework of the inherent "illusory optimism" (Patosha, 2019). This cognitive distortion, combined with the "myopia" effect described in the work of A. A. Nikiforov and O. N.
Antipina, which implies reliance on a short-term period, but threatening significant risks in the future, can together lead, for example, to a crisis and other socio-economic consequences. (Permitin)

The impact of this effect on the country's governance level can be particularly strong. Such an example is the adoption of prohibition in the USSR in the 1985 's. So, this campaign failed in the United States in the 1920s. At the initial stages, it seemed that the law had nothing but advantages: the demographic situation improved, the productivity of labor in factories increased, the number of crimes committed by the people being intoxicated decreased - in short, the American people became wealthier and healthier. But things turned out very differently. In the long run, the policy has led to an increase in crime, corruption, mortality, and drug addiction. And what do we see in 65 years? The policy that has repeatedly tried to be implemented in the USSR since the 1920s was finally implemented in 1985 by Mikhail Gorbachev. Despite many positive effects, the result was the same as in the USA. The campaign had a very negative impact on the wine industry, significantly reducing the supply of alcohol. The long-term supply curve (LRAS) reacted accordingly to the policy and, being completely inelastic, shifted to the left. Observing the same level of demand, it is clear that the price has increased, as it was in reality (about twice its previous level). The unsatisfied demand found its product in other markets, but already in black markets. The shadow economy began to grow steadily. After not holding out for 2 years, the law was repealed, but it was too late. In 1987, the economic crisis began. During this time, the state budget collapsed, because the alcohol market gave about $25 \%$ of revenues to the budget. With the beginning of the crisis, inflation rises. The cycle closes again if you remember all that was mentioned earlier.

Well, now we will continue to consider inflation expectations again. And in this topic, it is impossible not to say about the Fischer model (equation). It reflects the dependence of the nominal interest rate on 2 variables: the real interest rate and the expected rate of inflation.

$$
i=r+\pi
$$


This formula has only a few limitations: the first is accuracy, since from the point of view of mathematics it is correct to say that this formula is suitable for calculating the approximate level of the nominal interest rate, and the second is the borders of use since this formula is valid only for the rate of moderate inflation. However, this pattern allowed us to create the "Fischer's effect", which is that if the expected rate of inflation increases by 1 percentage point, then the nominal interest rate will increase by 1 percentage point, accordingly.

So, we should try to consider the impact of this on aggregated demand (AD) from the point of view of J.Keynes. In accordance with the effect of Keynes, the interest rate naturally causes a decrease in aggregate demand (AD). There is a reason for this. The growth rate means the growth rates of credit and reduction in real incomes of the population. It can be seen that in this model, too, behavioral mechanisms significantly influence aggregate demand. From a behavioral point of view, the effects described above can be factors that induce an increase in the nominal interest rate: the crowd effect, the information cascade, the waves of optimism and pessimism. All this together with" bounded rationality " changes the equilibrium point at the intersection of the $A D$ and AS curves in different models

Now let's look at another equally important discovery of behavioral macroeconomics. For example, Richard Thaler, a professor at the University of Chicago who won the 2017 Nobel Memorial Prize in Economic Sciences for his contributions to behavioral economics, co-wrote with Cass Sunstein in 2008 the book "Nudge: The architecture of choice", which reveals the theory of nudging. He stressed that under certain conditions, the context and presentation of options can influence the choice, not just the main product. R. Tyler defines the nudge as "any aspect of the decision-making process that encourages people to change their behavior in a certain way, without putting any restrictions on their choices." Let's look at the foreign experience of using "nudges" to change consumer decisions

For instance, Great Britain. In this country, the health care system is mainly socially oriented, and therefore almost completely free. However, to reduce the number of missed appointments of doctors for disrespectful reasons or without notification, in 2015, it was decided to introduce fines for this type of patient. (Pettinger, 2015) A system was introduced to send text reminders by SMS on the day of the visit or a certain number of days before the scheduled doctor's appointment to reduce absences. And it successfully increased the attendance (or aggregated demand). However, research in behavioral economics shows that changing SMS words can affect the success of the outcome. For example, if text messages refer to direct NHS expenses that patients are required to reimburse for a missed appointment (£160), this helps reduce the number of missed appointments from $11.1 \%$ to $8.5 \%$. (Safronchuk, 2017). Thus, it is clear that nudging can have some impact on the consumer, which in turn allows you to recover potential costs that the state would have incurred. But why did this method work so successfully, reducing the percentage of unfulfilled techniques by almost $3 \%$ ? I think another behavioral concept plays a very important role here, namely loss aversion. This is a well-known and important concept, which was discovered By D. Kahneman and A. Tversky, whom we have already mentioned in the framework of "illusory optimism". Loss aversion is one of several features of the value function built in the framework of the extremely important because of its practicality "theory of prospects" (Dietrich, 2010). The essence of the loss aversion property is the tendency of people to prefer to avoid losses rather than acquire equivalent benefits. It has been proven that the 'pain' of losing something is psychologically about twice as strong as the pleasure of receiving it (Sheresheva \& Kostanyan, 2016). In this case, the patient loses money, and he knows exactly how much money he loses. And it can be considered quite large. So, taking the statistics of average salaries for September 2019 in England, for example, Manchester, we will see a number equal to 1735 pounds. Even now, the fine is about $10 \%$ of the salary. However, excluding other mandatory expenses and taxes, we can assume that the percentage will be slightly higher. The effectiveness of the measure, for example, for residents of Manchester, which we have already discussed, is explained by another property of the value function of the "perspective theory", called decreasing sensitivity. So, with a salary that is a large amount of money, the difference would not 
be felt as much as with a smaller one. This simple truth put forward by D. Kahneman and A. Tversky, with the discovery of $R$. Thaler, has a significant impact on aggregate demand, reducing government spending, which in turn can be invested in other sectors of the economy and the state as a whole. This is a positive prerequisite for economic growth.

Another example of the effectiveness of "nudges" is also associated with the UK, but it is more important in terms of tax concerns. In 2010, British Prime Minister David Cameron created a new government unit connected to the studying of citizens ' behavior. Since then, a lot of effort has been devoted to developing a system that would reduce the number of tax non-payments. And the New York Times in one of its newspapers notes that the British authorities have significantly succeeded in this case. By coming up with a good text about the fact that most people with the same level of taxes have already paid this tax and sending it to taxpayers, the state managed to increase budget revenue by 210 million pounds (Tziokas, 2017). Because the United Kingdom is the second country after the United States that is most radically focused on the fact of non-payment of taxes, you can understand why this "push" has worked so effectively. Citizens do not like the idea of paying a fine for late tax payments, and therefore most people strive to pay the tax in time. So as not to lose more than the minimum set by the tax amount itself. This, it seems to be, is one of the manifestations of loss avoidance. Also, tax revenues are one of the few sources of state funds. Therefore, this example is a very positive prerequisite for stable economic growth, because the more this system is improved, the more amount of money received will be increased. This means that if all negative factors are taken as a constant, this is an excellent result and a direct hint of economic growth.

\section{CONCLUSION}

We found out how diverse the discoveries of scientists working in the field of behavioral economics are. All of them allow us to bring economic analysis closer to reality and confirm the opinion that the consumer is guided by cognitive distortions rather than rationalism when deciding. Although many distortions were identified in the late $\mathrm{XX}$ century and early $\mathrm{XXI}$ century, behavioral Economics as a separate branch of science that stands at the intersection of psychology and economics, formally appeared only recently. This is proved by the fact that the JEL code (E03) for behavioral macroeconomics exists only since 2017 (Hommes, 2018).

Nevertheless, the influence of behavioral economics on consumer decisions is significant, which means that the changes that occur in the economy are also significant. But in which direction do they go? In the direction of a growth or a decline? The answer largely depends on both the consumer and other subjects who use information about consumer mental processes.

So, the role of the consumer, from the point of view of behavioral economics, is, for example, to form a positive way of thinking that will allow you to cope with critical economic situations faster. Or in education to make the right decisions.

Other subjects may be government agencies representing the state, or various types of marketing companies. All of them form policies that try to use invisible means to direct the consumer to the place where (from the point of view of the subject implementing the policy) the best solution is. This means that it is rational to say that behavioral economics is a tool that can be used both for the benefit of the economy and for its harm.

\section{WORKS CITED}

Dietrich, C. (2010). Decision Making: Factors that Influence Decision Making, Heuristics Used, and Decision Outcomes. Inquiries Journal, 2(2), 1-3. Retrieved from http://www.inquiriesjournal.com/articles/180/decision-making-factors-that-influence-decisionmaking-heuristics-used-and-decision-outcomes

Hommes, C. (2018). Behavioral \& experimental macroeconomics and policy analysis: a complex systems approach. Working Paper Series 2201. Retrieved from https://ideas.repec.org/p/ecb/ecbwps/20182201.html 
Kahneman, D., \& Tversky, A. (2003). Rational Choice, Values, and Frames. Psychological Journal, 24(4), 31-42.

Kornilova, T. V., \& Tikhomirov, O. K. (1990). Making intelligent decisions in dialogue with a computer. Moscow: Moscow State University.

Makashova, N. (2015, 07 04). Britanskiye gosudarstvennyye bol'nitsy smogut shtrafovat' patsiyentov za neyavku na priyem. Retrieved from Maks Konsalting: https://mklondon.co.uk/news/u489/2015/07/04/8947

Nikiforov, A. A., \& Antipina, O. N. (2016). Behavioral macroeconomics: on the way to a new synthesis. Problems of Economics(12), 88-103.

Otrokhova, L. (2013). K probleme issledovaniya gruppovogo soznaniya. Retrieved from CyberLeninka: https://cyberleninka.ru/article/n/k-probleme-issledovaniya-gruppovogo-soznaniya

Patosha, O. I. (2019, Jan.). Psychological factors of economic decision making. Universum: Sotsial'naya psikhologiya, 55(1), 1-3. Retrieved from CyberLeninka: https://cyberleninka.ru/article/n/psihologicheskie-faktory-prinyatiya-ekonomicheskih-resheniy

Permitin, I. A. (n.d.). The current stage of development and theoretical achievements of behavioral economic theory. Retrieved from CyberLeninka: https://cyberleninka.ru/article/n/sovremennyyetap-razvitiya-i-teoreticheskie-dostizheniya-povedencheskoy-ekonomicheskoy-teorii/viewer

Pettinger, T. (2015, Nov.). Nudges. Retrieved from EconomicsHelp: https://www.economicshelp.org/blog/glossary/nudges/

Pocheptsov, G. G. (2016). Podtalkivaniye k pravil'nomu povedeniyu: britanskiy opyt. Retrieved from psyfactor.org: https://psyfactor.org/lib/nudges.htm

Safronchuk, M. (2017). Behavioral Economics in Macroeconomic Analysis. Academy Herald, 1, 45-48.

Sheresheva, M., \& Kostanyan, A. (2016, Aug. 16). Behavioral economics: a human model in economic theory and an assessment of the role of the state in this model (preprint). Retrieved from Lomonosov Moscow State

https://www.econ.msu.ru/sys/raw.php?o=32384\&p=attachment

University:

Tziokas, V. (2017, Nov. 23). Digital Transformation \& Behavioral Economics: Making Business Smarter Beyond Artificial Intelligence. Retrieved from The Journal Blog: https://blog.usejournal.com/digital-transformation-behavioral-economics-making-businesssmarter-beyond-artificial-a3f50c297f1c

Received for publication: 04.09 .2020

Revision received: $\quad 05.09 .2020$

Accepted for publication: 30.12 .2020

\section{How to cite this article?}

Style - APA Sixth Edition:

Vukolov, D. (2021, January 15). The behavioral economics: an influence of psychological factors on the economic growth. (Z. Cekerevac, Ed.) MEST Journal, 9(1), 199-206. doi:10.12709/mest.09.09.01.23

Style - Chicago Sixteenth Edition:

Vukolov, Dmitry. 2021. "The behavioral economics: an influence of psychological factors on the economic growth." Edited by Zoran Cekerevac. MEST Journal (MESTE) 9 (1): 199-206. doi:10.12709/mest.09.09.01.23. 
Style - GOST Name Sort:

Vukolov Dmitry The behavioral economics: an influence of psychological factors on the economic growth [Journal] // MEST Journal / ed. Cekerevac Zoran. - Belgrade - Toronto : MESTE, January 15, 2021. - 1 : Vol. 9. - pp. 199-206.

Style - Harvard Anglia:

Vukolov, D., 2021. The behavioral economics: an influence of psychological factors on the economic growth. MEST Journal, 15 January, 9(1), pp. 199-206.

Style - ISO 690 Numerical Reference:

The behavioral economics: an influence of psychological factors on the economic growth. Vukolov, Dmitry. [ed.] Zoran Cekerevac. 1, Belgrade - Toronto : MESTE, January 15, 2021, MEST Journal, Vol. 9, pp. 199-206 